\title{
14 \\ Building a data revolution in Indian country
}

\section{Desi Rodriguez-Lonebear}

\section{Introduction}

From Twitter to the World Bank, the data revolution is transforming business as usual. Everything from our spending habits to our health status is now captured as data for use by governments, industry, nongovernmental organisations (NGOs) and whoever can get access. Information about us is becoming a valuable global currency. With 90 per cent of data in the world created in the past two years alone (IBM, no date), we are undoubtedly in the data age. Yet, this unparalleled profusion of data does not serve everyone. Marginalised populations across the globe continue to face glaring data inequities. Indigenous peoples, for example, suffer from a dearth of relevant information about their populations, and this is so despite generations of contentious external data collection efforts in their communities. In the data mecca of the United States, American Indian tribes ${ }^{1}$ face a paucity of data about their own populations.

1 For the sake of brevity, I use American Indian tribe and tribe interchangeably throughout. I also utilise American Indian, Indian, Native American and indigenous peoples synonymously. 
American Indian nations, like other nations, are decision-making entities that need reliable information about their citizens. However, existing data on tribal populations are often limited to those developed by others - usually federal, state and local governments. Tribes must grapple with the task of building strong nations while utilising data that have been collected to advance the aims of other governments. I do five things in this chapter. First, I argue that data are not a new concept to American Indians; they have long been data gatherers and data experts. Second, I trace the movement of American Indian nations from data sovereignty to data dependence. Third, I review some of the data challenges now facing American Indian nations, including the current state of American Indian population data. Fourth, I explore the nascent data revolution now getting under way in Indian country as some tribes reclaim data sovereignty. Finally, I close by considering how tribal data sovereignty can be a powerful tool in decolonisation and in pursuit of tribal development goals.

\section{Our peoples have always been data gatherers}

Science and technology are often considered markers of civilisation, with progress measured in units of data (Misa et al. 2003). Despite centuries of indigenous knowledge production steeped in histories of data collection and analysis (Cajete 1999; Smith 1999), progress is defined largely in Western terms and measured by Western-identified and controlled indices. In the United States, the hegemony of the Western approach means that information that does not originate in or is not validated by Western constructs is rejected or coopted at best, and destroyed at worst. Yet, contrary to colonial narratives of savagery and unsophistication, indigenous peoples were relentlessly empirical with advanced systems of knowledge. For indigenous peoples, data were everywhere, and survival was often tied to one's ability to gather, analyse and share this knowledge. The winter counts by the Plains Indians are an example of the meticulous and methodological nature of indigenous data. The Lakota, Blackfeet and other Plains tribes recorded winter counts on animal hides to enumerate important aspects of their world. These detailed counts included numbers of tribal citizens, allies, enemies, wild game, lodges and so on: histories and assemblages of data that were instruments 
of survival. They are among the earliest population and wildlife records in all of North America (Raczka 1979). Another instance of indigenous peoples' detailed data-keeping are the totem poles carved in the Pacific North-West. Totem poles document everything from family histories and tribal origin stories to achievements, marriages and land rights (Stewart 1993). While the purpose and significance of totem poles vary greatly across the peoples of the Pacific North-West, they all hold deep meaning to their creators and remain relevant and valuable data sources today.

An additional example comes from the oral history of my tribe, the Northern Cheyenne. We are often labelled 'anti-progress' due to our intergenerational stance-despite pervasive poverty-against developing lucrative coal and natural gas deposits on our lands. Reasons for and against resource development vary and factions within the tribe abound. However, one salient argument against development comes from the oral history of the Cheyenne people. The Cheyenne prophet Sweet Medicine, one of our most powerful figures, foretold that the Cheyenne would one day encounter a black stone beneath our lands. Sweet Medicine warned that this stone was to be left alone if the Cheyenne were to remain Cheyenne. This prophecy, along with many others by Sweet Medicine, has been passed down from generation to generation. They have been shared by Cheyenne and non-Cheyenne alike (Powell 1979), and continue to influence contemporary decisions within the tribe. As with many tribes, Cheyenne oral history remains a critical source of data as we grapple with contemporary issues. It directly challenges the idea of data as products of modernity with little relevance to indigenous lived experiences or traditions. These and other examples indicate that the indigenous peoples of the United States identified, gathered and used essential data in pursuit of their own goals.

\section{From data sovereignty to data dependence}

The word 'data' comes from the Latin datum, meaning 'something given' (OED Online, no date). However, indigenous experiences under colonial control suggest that data more often means 'something taken'. An extreme, yet common, version of the taking of indigenous data stems from the perverse fascination of Europeans with the faculties 
and nature of indigenous peoples turned into objects of research (Smith 1999; see also the FNIGC, this volume). This has been apparent in the United States in the desecration of countless Indian graves, looting of funerary objects and theft of human remains. The remains of thousands of American Indians held in museums and private collections across the globe illustrate the ultimate theft of indigenous peoples' data: their bodies (Fine-Dare 2002). The life of Ishi, a native man who was sensationalised as the last member of the Yahi tribe in the early-twentieth century, exemplifies how the 'taking' of indigenous knowledge and the theft of Indian remains played a significant role in advancing academic disciplines - markedly, American anthropology. ${ }^{2}$ Ishi's story also demonstrates how the exertion of tribal sovereignty over data can achieve some measure of justice.

Ishi is said to have wandered out of the wild in 1911 and was 'taken in' by University of California anthropologist Alfred Kroeber (Kroeber 1961). He spent the last years of his life as a living exhibit at the university's Museum of Anthropology, drawing huge crowds (Starn 2004). Kroeber and others talked at length with Ishi, trying to learn all they could about his language and the ways of his people. In effect, Ishi was a source of data and provided an opportunity to secure the data that he and his people had gathered over the generations. Ultimately, even Ishi's brain became data to be secured. After his death, his brain was removed and sent to the National Museum of Natural History as a 'gift from the University of California' (Starn 2004). In 1997, four federally recognised tribes of the Maidu people ${ }^{3}$ of northern California passed a resolution to locate Ishi's brain. The tribes leveraged their relationships with state and local governments, gaining support for the investigation from the US Forest Service, the City of Oroville and the Butte County Board of Supervisors (Rockafellar, no date). The tribes' efforts resulted in an official inquiry into the location of Ishi's brain, which was ultimately discovered in the Smithsonian Institution's collections. The National Museum of the Native American Act of 1989

2 For an example, see Mead (1961); for a critique, see Deloria (1969).

3 These four tribes banded together to form the Butte County Native American Cultural Committee, which served as the collective advocating for Ishi's repatriation. 
mandates the return of Native American human remains and associated funerary objects if requested by federally recognised tribes. ${ }^{4}$ Ishi's brain was eventually repatriated to the Redding Rancheria and Pit River tribes, restoring their control over a small portion of tribal data and gaining some semblance of overdue justice.

The concept of data is imbued with a host of meanings within and across contexts. To some, it is simply information, while, for others, it is the very pulse of a revolution. In the indigenous world, data have a contentious history tied to the survival of native peoples on one hand, and to the instruments of the coloniser on the other. Indigenous data engagement in the United States is inextricably tied to the subjugation of American Indians and federal policies of Indian extermination and assimilation. Historically, this relationship is apparent in the concurrent exclusion of American Indians from official statistics and the peak of the colonial engine. Article I, section 2 of the US Constitution mandates a census be taken every 10 years to determine congressional representation by apportionment. The only people explicitly excluded from this count are 'Indians not taxed'defined as 'those Indians living on reservations or those roaming in unsettled areas of the country' (Collins 2006). Under this definition, the majority of American Indians were deliberately omitted from the US Census for over 100 years (1790-1924) until the passage of the 1924 Indian Citizenship Act. ${ }^{5}$ While censuses are intended to serve as the pre-eminent source of data on all individuals of a population, the act of counting people is political (Walter \& Andersen 2013). The exclusion of American Indians from official enumeration throughout the nineteenth century justified the colonial narrative of a vast and unpopulated land in the west ripe for settling. However, the Indian Wars told a very different story (Utley \& Washburn 1985).

4 See 103 STAT.1336, Public Law 101-185, National Museum of the American Indian Act, 28 November 1989.

5 From 1885 to 1940 , special Indian census rolls were collected by federal Indian agents in charge of Indian reservations. These counts were collected at the discretion of Indian agents and were maintained separately from the general decennial census. Often, these rolls became the basis of tribal enrolment policy and federal tribal recognition. See File 595276, Indian Census Rolls, 1885-1941, Record Group 75: Records of the Bureau of Indian Affairs, 1793-1999, National Archives Building, Washington, DC. 
As the Indian Wars concluded and American Indians were relegated to reservations, much of the data gathering on which they depended for generations also forcibly ceased. Removal from their ancestral homelands, coupled with the decimation of wild game, population decline and the boarding school system, stripped Indians of their traditional sources of knowledge and survival. It also marked the inception of federal assimilation policies, starting with the General Allotment Act of 1887, which sought to 'civilise' the Indians by privatising tribal lands (Otis \& Prucha 1973). This new chapter in federal-Indian relations precipitated a shift to data dependency for American Indian tribes. Indigenous data transitioned from a means of survival to mechanisms of federal administration. In 1824, the Bureau of Indian Affairs (BIA) was established under the War Department to oversee American Indians. It was charged with 'the administration of the fund for the civilization of the Indians' ${ }^{6}$ The BIA was later relocated to the Department of the Interior, where American Indian populations are now managed alongside national parks, natural resources and fish and wildlife.

Though no longer designated enemies of war, American Indians are still treated as a population in need of federal oversight. Often in competition with each other, tribes vie for federal grants disbursed through a host of agencies, including the BIA, the Department of Housing and Urban Development (HUD) and the Administration for Native Americans, among others. Given the destruction of traditional tribal economies in the aftermath of colonisation, these federal monies sustain vital tribal services on reservation lands, such as health care, education and housing. The reality is that contemporary tribal governments endure varying stages of federal dependency, including data dependency. The data collection activities of tribes now largely revolve around mandatory federal grant reporting, and many tribes employ grant officers or administrators to oversee these efforts.

6 See House Document No. 146, 19th Congress, 1st session, serial 138: 6. 


\section{The key issue: data by whom for whom?}

Data sovereignty deals with the right and ability of tribes to develop their own systems for gathering and using data and to influence the collection of data by external actors. With respect to the latter, the United States has not kept pace with some other countries, such as New Zealand, where national statistics offices are becoming more responsive to the data priorities of Māori tribes (Walling et al. 2009; Kukutai \& Rarere 2013). The focus of American Indian demography remains on the national and regional levels, utilising census counts of American Indians. Too often missing from this data picture is analysis at the tribal population or subpopulation level. American Indian tribes are policymaking bodies currently operating without accurate and reliable data that are or can be disaggregated at levels that facilitate sound tribal policy. Both the tribal pursuit of nation rebuilding and the federal investment pursuant to the fiduciary relationship between tribes and the US Government point to the need for more comprehensive tribal data systems.

Many of the issues tribes face in using existing data about their citizens stem from the use of inconsistent criteria to delimit tribal populations in tribal, county, state and federal datasets. Unlike in other countries, in the United States no statistical data standard exists to govern the collection and reporting of American Indian tribal population data across agencies. ${ }^{7}$ Todd (2012) compiled a list of 295 sources of Indian country data, which provides a window into the daunting maze that tribes must work through to ascertain information about their populations. Less than 2 per cent of the data reported in this exhaustive list are from a tribal source. Five sources about tribal governance structures are reported from tribal constitutions, and one account of historical tribal data was identified. The remaining 98 per cent of sources span the US Census, administrative agencies such as the BIA and HUD, national surveys and numerous scholarly references.

Table 14.1 provides one illustration of the resulting problems. It lists 10 data sources of significance to Indian country and how each source identifies tribal citizens. This provides a small glimpse into

7 See Statistics New Zealand's Statistical Standard for iwi (tribes) as an example: stats.govt.nz/ methods/classifications-and-standards/classification-related-stats-standards/iwi.aspx. 
the competing data landscape that tribal leaders, communities and researchers face. Confronted with hundreds of such data sources and no consistent standards or measures, it is small wonder tribes often find effective policymaking difficult.

Table 14.1 Tribal data sources and identifiers

\begin{tabular}{|l|l|}
\hline Data source & Tribal identifier \\
\hline US Census & Self-identification \\
\hline American Community Survey & Self-identification \\
\hline Tribal Enrolment Data & $\begin{array}{l}\text { Minimum blood quantum, lineal descent and residency } \\
\text { are the most common measures enforced by tribes }\end{array}$ \\
\hline $\begin{array}{l}\text { Department of Housing } \\
\text { and Urban Development }\end{array}$ & Census counts \\
\hline $\begin{array}{l}\text { Department of Education } \\
\text { Scholarships }\end{array}$ & $\begin{array}{l}\text { Tribal enrolment verification; Certificate Degree of Indian } \\
\text { Blood from the Bureau of Indian Affairs }\end{array}$ \\
\hline Bureau of Indian Affairs & $\begin{array}{l}\text { A tribal service population is defined as all American } \\
\text { Indians and Alaska Natives, citizens and non-citizens, } \\
\text { living 'on or near' a tribe's reservation during the } \\
\text { calendar year and who were eligible for Bureau of Indian } \\
\text { Affairs-funded services (see Evans \& Topoleski 2002) }\end{array}$ \\
\hline Indian Health Service & $\begin{array}{l}\text { Federally recognised tribal member living within } \\
\text { the service area }\end{array}$ \\
\hline State and county agencies & Census counts \\
\hline Official vital statistics & $\begin{array}{l}\text { Lack of data at the tribal level inhibits the ability to } \\
\text { calculate vital statistics for enrolled tribal populations }\end{array}$ \\
\hline US Armed Forces & $\begin{array}{l}\text { Certificate Degree of Indian Blood from the Bureau } \\
\text { of Indian Affairs }\end{array}$ \\
\hline
\end{tabular}

Source: The author's research.

Furthermore, little systematic evidence has been gathered to date to identify what types of tribal data exist, what processes govern access to those data, what analyses have been conducted using those data and what use these analyses have been to tribes. The tribal data that do exist are often framed as inferior to data collected by other governments. For example, in 2015 the state of Montana issued a press release explaining that the state's Department of Labor and Industry will now calculate monthly unemployment rates for Montana's seven Indian reservations. Previously, the state calculated only annual reservation statistics. The department's chief economist issued the following reason: 'Reservations were struggling to find accurate numbers, and some were creating their own methods' (Associated 
Press 2015). This statement ignores the fact that tribes often are in the best position to capture the realities of their tribal citizens' situations. Given the shortage of skilled data analysts throughout Indian country, analysing data in statistically sound ways that yield robust figures may be a challenge. But both tribal and state governments would benefit from an initiative that focused on assisting tribes to improve their data capabilities to take advantage of their insider knowledge. Instead, Montana's chief economist further entrenches the idea that state statistics are valid and tribal statistics are the ones in need of correction.

Also missing from this story are those data that can transform native communities. Walter \& Andersen (2013: 14) note the power of statistics to perpetuate 'very narrow, but largely accepted lenses' through which governments and researchers alike understand indigenous peoples. Mainstream understandings of indigenous peoples are constrained by data that inform the prevailing narratives. We witness this time and again in native communities. High rates of suicide, diabetes, unemployment and substance abuse are but a few of the pervasive deficit statistics used to characterise native populations, so it is time to develop our own data that speak to our strengths. For example, what do we know about tribal youth, who make up the majority of tribal populations? Do they desire to return home after getting their education to help their nations? These are the 'data warriors' we need to steer the data revolution.

It is evident that dominant demographic approaches and methods remain limited in facilitating tribal development. The 'collision of systems' that characterises the collection of indigenous data by the state is pervasive across Indian country (Morphy 2004). In light of this, census and administrative agencies are criticised for failing to fully appreciate the complexity of native identities and communities. Scholars in indigenous demography contend that this is largely because official data drive mainstream agendas and do not reflect indigenous social structures, realities or aspirations (Taylor 2009; Axelsson \& Sköld 2011). This issue needs to be addressed from both sides. Tribal data sovereignty has two prongs. On one side, it involves tribes exercising their sovereignty by developing tribal data sources; on the other, it involves improved collection of official statistics on tribal citizens and finding ways to make those statistics maximally useful to tribes. Despite the limitations of official statistics, they remain 
critical sources of evidence that tribes can use in pursuit of their goals. This will require meaningful and deliberate partnership, not just consultation, between American Indian tribes and the US Census Bureau and other federal, state and county agencies.

\section{The case of tribal population data}

Tribal population data provide an excellent example of both the data problem and the start of a possible solution. Tribal citizenship and American Indian identity are not mutually inclusive. A key aspect of tribal sovereignty is the sole right of tribes to determine tribal citizenship. This is one of the few areas of Indian affairs that the federal government explicitly leaves to the prerogative of tribes. Tribes determine citizenship through various means including ancestry, residency, maternal/paternal lineage and minimum blood quantum. ${ }^{8}$ Without delving into the tribal blood quantum debate, suffice to say that every tribe has clearly defined tribal population boundaries. Though tribes maintain records on their citizens, these data are rarely used by any other entity. The federal government does not rely on tribal records for official tribal population numbers; instead, most agencies utilise tribal self-identification counts from the US Census. This has serious implications for tribes because tribal census counts are used to calculate federal funding formulas, which in turn allocate money for vital services to American Indian tribes. For example, HUD distributes US $\$ 650$ million annually to tribes through the Indian Housing Block Grant, based largely on population figures from the census (Sackett 2015).

Federal funding formulas directly test tribal data sovereignty as they prioritise tribal data collected by the federal government over those collected by tribes for national decision-making. For HUD grants, tribes can challenge the census counts; however, doing so is particularly burdensome as tribes must show that their data were collected in the same manner as for the US Census and, ultimately,

8 The US Government first implemented blood quantum as the basis for racially identifying American Indians in the late-nineteenth century - most markedly, beginning with the 1877 Dawes Act (also known as the General Allotment Act). The concept stems from the now debunked quasi-scientific belief that blood was the carrier of not only genetic material, but also cultural traits and social behaviour (Snipp 1989). This belief later influenced the eugenics movement (Berkhofer 1978). 
HUD has the final authority to accept or dismiss a tribal challenge (HUD 2012). Over the course of interviews with 15 tribal leaders about tribal data, I consistently heard that the census numbers do not accurately enumerate tribal populations - specifically, that the census undercounts their tribal citizens. ${ }^{9}$ While there are no comparative studies in the United States, international research supports this position, demonstrating an incongruence between tribal populations enumerated in tribal data sources and those in official statistics. A tribal demographic study in New Zealand found significant variation in the characteristics of a tribal population enumerated in the New Zealand Census and those of the tribe's own citizenship register, particularly with regard to gender and age (Walling et al. 2009). ${ }^{10}$

In the United States, scholarship is focused on the American Indian and Alaska Native (AIAN) aggregate population, with an emphasis on population size, composition, undercounting and processes of changing racial identification (Eschbach 1995; Nagel 1996; Sandefur et al. 1996; Snipp 1997; Liebler \& Ortyl 2014). Little attention has been paid to tribal demography. This is a major oversight given the political, social and cultural importance of American Indian tribes as sovereign nations within the US political system. Furthermore, as governance entities, tribes are the pre-eminent units of measurement for the collective dispersal of federal funding. Regarding tribal data from the US Census, one must first ask whether capturing tribal populations in the census is even within the purview of the federal government given the reach of tribal sovereignty. What is the value of self-identified tribal counts in the US Census if tribes maintain their own citizenship records? Instead of collecting self-identified tribal counts, should the US Census Bureau invest in tribal capacity building and tribal data infrastructure to support tribal censuses?

Beyond these questions of principle, there is also the methodological question of whether the US Census can accurately enumerate the general AIAN population, much less tribal subpopulations. American Indians and Alaska Natives experienced the largest undercount

9 Based on 15 personal interviews with tribal leaders at the National Congress of American Indians Mid-Year Conference in Minneapolis, Minnesota, 20 June - 1 July 2015. This research was approved by the University of Waikato Faculty of Arts and Social Sciences Human Research Ethics Committee on 18 February 2015.

10 I seek to undertake similar research comparing American Indian tribal data with US Census data as part of an upcoming research project. 
(4.9 per cent) of any racial or ethnic group in the 2010 census (US Census Bureau 2012). Currently, the Census Bureau is testing the possibility of a tribal enrolment question in the 2020 census. This question will enable more detailed analyses of self-identified tribal populations and could perhaps yield more accurate tribal counts. Conversely, nonresponse to the enrolment question could be high and thus contribute to more data inequities for American Indians and Alaska Natives. In 2015-16, the US Census Bureau hosted eight tribal consultations to discuss the tribal enrolment question with tribal leaders. While an official report is yet to be released, tribal leaders have made clear that this is a matter of tribal sovereignty and that such decisions require more than mere consultation, but rather genuine collaboration and careful joint deliberation (El Nasser 2015).

\section{The pursuit of tribal data sovereignty}

Today, there is a tribal data revolution under way in the United States. Some tribes are retaking control of data governance. In particular, the 25 per cent $(n=155)$ of federally recognised tribes that are now designated 'self-governance tribes' ${ }^{\prime 1}$ are leaders in the data revolution. A self-governance designation enables tribes to hold the federal government accountable to its trust responsibility to Indian tribes with limited federal intervention. These tribes are able to restructure federal programs and utilise federal funding as they see fit to meet the needs of their citizens. As these tribes are already exercising tribal sovereignty to a greater extent than 'direct service tribes', they are ideally positioned to guide the tribal data revolution.

'Tribal sovereignty is only as strong as we exercise it. ${ }^{12}$ This statement by a mentor and former tribal president of the Northern Cheyenne Nation, John J. Robinson, describes the precarious position of Indian tribes as quasi-sovereign nations operating within a federal governance structure that was founded on the erosion of tribal sovereignty. It speaks further to the need for tribes to engage in governance endeavours on par with any other sovereign. The legal foundation

11 Tribes can apply for 'self-governance' designation per the Tribal Self Governance Act of 1995 (PL 103-413).

12 Personal communication with John J. Robinson, former president of the Northern Cheyenne Nation (2012-13), 10 October 2015. 
of tribal sovereignty vis-a-vis the US Government is critical to understanding the opportunities and challenges inherent in American Indian data governance. Each of the 567 federally recognised American Indian tribes has their own nation-to-nation relationship with the US Government, which is expressly addressed in Article 1, section 8 of the US Constitution-also referred to as the 'Commerce Clause'. In the 1830s, a series of Supreme Court decisions known as the Marshall Trilogy delineated the sovereignty of tribes as 'domestic dependent nations' (Fixico 2008). The sovereign status of Indian tribes enables legal and political authority over tribal citizens and activities occurring within the jurisdiction of tribal lands (Davies \& Clow 2009). However, the state of domestic dependency on the federal government leads to a well-argued position in federal Indian law that tribal sovereignty exists 'only where the acts of Congress have not displaced it' (Gould 1996: 811). While American Indian tribes continuously fight legal battles to uphold sovereignty and tribal jurisdiction, less attention is paid to tribal sovereignty as a self-reinforcing exercise. Data governance, for example, is facilitated by tribal sovereignty; it also reinforces tribal sovereignty by providing the tribal evidence base required to advance self-determination.

Tribal sovereignty over tribal citizens and resources extends to control over data and research (NCAI Policy Research Center 2012). Data sovereignty explains the process by which American Indian tribes regulate all aspects of tribal data, including access, collection, management, analysis and reporting. Viewing data governance through the lens of tribal sovereignty strengthens the nation-tonation relationship between tribes and other sovereigns because it commands policy development on tribal terms. For too long, tribes have relied on external data sources for tribal decision-making. This dependency is no less a threat to tribal sovereignty than any other legal constraint facing tribes. The necessity to ground data within a tribal sovereignty framework is critical given that the information tribes need to support their own conceptions of development is not being produced by colonial administrative systems. Tribal data are perhaps the most valuable tools of self-determination because they drive tribal nation building by tribes for tribes.

Ripples of change are starting to emanate from tribes. This was the sentiment I gathered from my interviews with tribal leaders at the National Congress of American Indians Mid-Year Conference in 
July 2015. These semi-structured interviews with tribal leaders covered a range of data topics, including current tribal data use and infrastructure, data needs and the connection between tribal sovereignty and data. As I am still in the process of analysing these interviews, a complete analysis is not possible in this chapter. ${ }^{13}$ However, I wish to address the unexpected response I received to one set of questions because it leads to an important conclusion about how the data revolution can take root in Indian country.

I asked the following questions pertaining to tribal enrolment:

Please tell me about your tribe's enrolment policy and process for enrolment. How is this information captured and maintained? Does it differ for tribal citizens who live on the reservation or off?

My intent in asking these questions was to understand the mechanisms and structures of tribal enrolment systems. Much to my surprise, the conversations that ensued included extensive discussion of attitudes towards blood quantum ${ }^{14}$ and citizenship. Our conversations turned very personal as tribal leaders shared examples from within their own families of how the exclusivity of blood quantum is harmful. As these were semi-structured interviews, our conversations were allowed to evolve organically. Several of my interviewees talked at length about the need to depart from blood quantum. One mentioned the sense of responsibility he felt as a tribal leader to change the system. This is evident in his statement: 'We have to do something. Just because these kids don't have enough blood, that doesn't make them any less [name of tribe].' Other tribal leaders expressed similar concerns about the future of their tribes if current and future generations cannot formally claim a tribal identity. Moreover, the role of tribal data in advancing citizenship changes became clear. One of the most impassioned interviewees said:

We need data! I can't go to my fellow legislators and talk to them about dropping the blood quantum unless I have data to show them how in five years we're going to be here, in 10 years we're going to be here [referring to decreases in the size of the tribe]. They'll just think $I^{\prime} m$ doing this to get my cousin enrolled or something. That's why we need the data.

13 I anticipate publishing my findings from these data sovereignty interviews with tribal leaders towards the end of 2016.

14 See Note 9 for more details on blood quantum. 
This conversation highlights a critical connection between tribal decision-making and tribal data. This tribal leader referred to data as objective - the opposite of a personal motivation. The importance of having unbiased evidence when developing strategies for tribal decisions, especially those steeped in controversy, cannot be overstated. Moreover, this statement identifies another connection between tribal data and tribal survival. All but one of the tribal leaders I interviewed were concerned about the future of their tribes if citizenship criteria remained in their current state. Further, there is a sense of urgency with which tribal leaders feel they must act to better align citizenship criteria and the demographic realities of their populations. To this end, they identified data as a critical tool. Intertribal partnerships - tribes helping tribes - must be a key component of the data sovereignty revolution in Indian country.

I asked the same tribal leader who shared the above quote to elaborate on the data to which he was referring. He explained that his tribe needs all kinds of data, but especially population projections. To that end, the importance of tribal population projections was also evident in a project undertaken by the Minnesota Chippewa Tribe (MCT) from 2012 to 2013. The MCT contracted with a research firm, Wilder Research, to conduct a series of tribal population projections based on hypothetical citizenship criteria to evaluate tribal citizenship changes (MartinRogers \& Gillaspy 2014). The MCT project, in addition to being an excellent example of tribal demographic research, demonstrates how 'by tribes for tribes' does not mean that external expertise cannot be utilised. Data sovereignty is about tribal control: control over who, what, when, where and why for all data projects pertaining to tribal citizens and resources. While the ultimate goal might be 100 per cent 'by us for us', the reality is that many tribes are not in a position to undertake expansive research projects that require extensive technical infrastructure, time and skills. Securing the right research expertise and steering the course are also important exercises of data sovereignty. 


\section{Concluding thoughts: the foundation of a data revolution}

Tribes in the United States are still catching up to the levels of indigenous data governance occurring in our sister countries: New Zealand, Australia and Canada. In talking to tribal leaders and scanning the data landscape of Indian country, it is promising to at least say we are moving in the right direction. Each of the tribal leaders with whom I spoke is a visionary; they all expressed the view that the futures of their tribes need to be built on data that are controlled by tribes. One of the biggest barriers expressed by all 15 tribal leaders in regards to tribal data development was the need for skilled staff to meet their data needs. All Indian tribes are currently facing the same data circumstances: they encounter gaps in their own tribal data infrastructure; they are subject to administrative data collections that do not meet their needs; they contend with problematic and inaccurate enumeration by other sovereigns; and they face barriers to creating a skilled data workforce, or 'data warriors'. Despite these resounding obstacles, we see that tribes are engaging in data sovereignty projects and developing best practices that other tribes can utilise to meet similar objectives. One of the obstacles, however, is that we still operate in silos in Indian country. It is time to move beyond these silos and embrace intertribal and international indigenous data partnerships to pave the way for data sovereignty. The data sovereignty revolution in Indian country is going to be built tribe by tribe and community by community. Reclaiming the right to understand the diverse realities of our peoples on our terms and to chart sustainable courses for future generations is a matter of contemporary survival for indigenous peoples.

A tribal leader whom I had the honour to interview powerfully summarised the transcendent connection between tribal data and tribal governance: 'Sovereignty as tribal nations was given to us by the Creator. It is sacred. Data to exercise our sovereignty is also sacred. ${ }^{15}$ This statement illustrates how the autonomy of Indian tribes extends far beyond the quasi-sovereign status afforded by the federal government. Indigenous peoples and tribal nations have survived despite every effort to ensure our demise. The key to our survival is

15 Personal interview with tribal leader at the National Congress of American Indians Mid-Year Conference in Minneapolis, Minnesota, 1 July 2015. 
the fact that our peoples have always been data gatherers. Whereas our ancestors practised data gathering for survival and resistance, today, tribes are engaged in data gathering for sovereignty. Yet, I question whether there is in fact a difference. Tribal data building continues as a critical catalyst for tribal nation rebuilding. In the United States, we are witnessing the beginning of a paradigm shift in which American Indian tribes are becoming data gatherers again, reclaiming the data-rich practices of survival that our ancestors employed since time immemorial. Drawing from this tradition, tribes are disrupting the legacy of colonisation and systems of data administration to which they have been subject. The tribal data revolution demands new approaches, new warriors, new structures and new partnerships to meet the contemporary challenges of tribal data governance in the twenty-first century.

\section{References}

Associated Press (2015). For first time, Montana reports unemployment rate on reservations. Billings Gazette, 19 June 2015, billingsgazette. $\mathrm{com} /$ news/state-and-regional/montana/for-first-time-montanareportsunemployment-rate-on-reservations/article_f8a0d505-effb5d29-b870-bebla26ebfc0.html.

Axelsson P \& Sköld P (2011). Indigenous peoples and demography: the complex relation between identity and statistics, Berghahn Books, New York.

Berkhofer R (1978). The white man's Indian: images of the American Indian from Columbus to the present, Knopf, New York.

Cajete G (1999). A people's ecology: explorations in sustainable living, Clear Light, Santa Fe, NM.

Collins JP (2006). Native Americans in the census, 1860-1890. Prologue 38(2)(Summer), archives.gov/publications/prologue/2006/summer/ indian-census.html.

Davies W \& Clow R (2009). American Indian sovereignty and law: an annotated bibliography, Scarecrow Press, Lanham, Md.

Deloria V (1969). Custer died for your sins: an Indian manifesto, Macmillan, New York. 
El Nasser H (2015). US Census challenge: counting every Native American and Alaska Native. Al Jazeera America, 3 November 2015, america.aljazeera.com/articles/2015/11/3/us-census-challengecounting-every-american-indian-and-alaska-native.html.

Eschbach K (1995). The enduring and vanishing American Indian: American Indian population growth and intermarriage in 1990. Ethnic and Racial Studies 18(1):89-108.

Evans WN \& Topoleski JH (2002). The social and economic impact of Native American casinos, NBER Working Paper 9198, National Bureau of Economic Research, Cambridge, Mass.

Fine-Dare K (2002). Grave injustice: the American Indian repatriation movement and NAGPRA, University of Nebraska Press, Lincoln, Nebr.

Fixico D (2008). Treaties with American Indians: an encyclopedia of rights, conflicts, and sovereignty, ABC-CLIO, Santa Barbara, CA.

Gould SL (1996). The consent paradigm: tribal sovereignty at the millennium. Columbia Law Review 96(4):809-902.

IBM (no date). Bringing big data to the enterprise. IBM InfoSphere Platform, IBM, New York, www-01.ibm.com/software/data/bigdata/ what-is-big-data.html.

Kroeber T (1961). Ishi in two worlds: a biography of the last wild Indian in North America, University of California Press, Berkeley, CA.

Kukutai T \& Rarere M (2013). Tracking patterns of tribal identification in the New Zealand Census, 1991-2006. New Zealand Population Review 39:1-24.

Liebler C \& Ortyl T (2014). More than one million new America Indians in 2000: who are they? Demography 51(3):1101-30.

MartinRogers N \& Gillaspy T (2014). Minnesota Chippewa Tribe population projections methodology report, Wilder Research, St Paul, mnchippewatribe.org/pdf/MCT\%20Methodology\%20Report.pdf.

Mead M (1961). Coming of age in Samoa: a psychological study of primitive youth for Western civilization, Morrow, New York. 
Misa T, Brey P \& Feenberg A (2003). Modernity and technology, MIT Press, Cambridge, Mass.

Morphy F (2004). Indigenous household structures and ABS definitions of the family: what happens when systems collide, and does it matter?, CAEPR Working Paper No. 26/2004, Centre for Aboriginal Economic Policy Research, The Australian National University, Canberra.

Nagel J (1996). American Indian ethnic renewal: red power and the resurgence of identity and culture, Oxford University Press, New York.

National Congress of American Indians (NCAI) Policy Research Center (2012). Walk softly and listen carefully: building research relationships with tribal communities, NCAI, Washington, DC.

Otis D and Prucha F (1973). The Dawes Act and the allotment of Indian lands, University of Oklahoma Press, Norman, OK.

Oxford English Dictionary (OED) Online (no date). Oxford English dictionary, Oxford University Press, Oxford, oxforddictionaries. com/us/definition/american_english/datum.

Powell P (1979). Sweet Medicine, University of Oklahoma Press, Norman, OK.

Raczka P (1979). Winter count: a history of the Blackfoot people, Oldman River Culture Center, Brocket, Alberta.

Rockafellar N (no date). The story of Ishi: a chronology, University of California, Berkeley, history.library.ucsf.edu/ishi.html.

Sackett C (2015). Who counts? Identifying Native American populations. Evidence Matters (Spring), US Department of Housing and Urban Development, Washington, DC, huduser.gov/portal/ periodicals/em/spring 15/highlight2.html.

Sandefur G, Rindfuss R \& Cohen B (1996). Changing numbers, changing needs: American Indian demography and public health, National Academy Press, Washington, DC.

Smith LT (1999). Decolonizing methodologies: research and indigenous peoples, Zed Books, London. 
Snipp CM (1989). American Indians: the first of this land, Russell Sage Foundation, New York.

Snipp CM (1997). The size and distribution of the American Indian population: fertility, mortality, migration, and residence. Population Research and Policy Review 16:61-93.

Starn O (2004). Ishi's brain: in search of America's last 'wild' Indian, WW Norton \& Company, New York.

Stewart H (1993). Looking at totem poles, Douglas \& McIntyre \& University of Washington Press, Vancouver \& Seattle.

Taylor J (2009). Indigenous demography and public policy in Australia: population or peoples? Journal of Population Research 26:115-30.

Todd RM (2012). Indian country economic development: data and data gaps. Federal Reserve Bank of Minneapolis, Minneapolis, minneapolisfed.org/community/indian-country/events/ /media/ Files/community/indiancountry/Todd_Data_and_Data_Gaps_ Paper.pdf.

United States Census Bureau (2012). Census Bureau releases estimates of undercount and overcount in the 2010 census, Media release, Washington, DC, 22 May 2012.

United States Department of Housing and Urban Development (HUD) (2012). Challenging US decennial census data: guidelines for the Indian Housing Block Grant Formula, Media release, Washington, DC, 31 July 2012.

Utley RM \& Washburn WE (1985). The Indian wars, American Heritage, New York.

Walling J, Small-Rodriguez D \& Kukutai T (2009). Tallying tribes: Waikato-Tainui in the census and iwi register. Social Policy Journal of New Zealand 36:2-15.

Walter M \& Andersen C (2013). Indigenous statistics: a quantitative research methodology, Left Coast Press, Walnut Creek, CA. 
This text is taken from Indigenous Data Sovereignty: Toward an agenda, edited by Tahu Kukutai and John Taylor, published 2016 by ANU Press, The Australian National University, Canberra, Australia. 